\title{
Spatial structure of relaxation events and crab settlement in the northern California upwelling system
}

\author{
Stephen R. Wing ${ }^{1,2,}$, Louis W. Botsford ${ }^{1,2}$, John L. Largier ${ }^{3}$, Lance E. Morgan ${ }^{1,2}$ \\ ${ }^{1}$ Wildlife, Fish and Conservation Biology, University of California, Davis, California 95616, USA \\ ${ }^{2}$ Bodega Marine Laboratory, PO Box 247, Bodega Bay, California 94923, USA \\ ${ }^{3}$ Center for Coastal Studies, Scripps Institution of Oceanography, La Jolla, California 92093-0209, USA
}

\begin{abstract}
During spring and summer 1993, we monitored settlement of crabs (primarily Cancer spp.) and sea urchins Strongylocentrotus spp. in conjunction with physical variables associated with coastal circulation to investigate how physical conditions influence the spatial distribution of recruitment along the coast. Observations were made along a $100 \mathrm{~km}$ stretch of the northern California coast (USA), from the Gulf of the Farallones north to Point Arena. Temperature, salinity and wind stress data indicated fluctuations in upwelling and provided evidence for the alongshore, northward flow of warm, low salinity water during upwelling relaxation events which typically lasted several days. On a weekly time scale, crab settlement was positively correlated with temperature, and negatively correlated with salinity, indicating that settlement occurred during relaxation events. Correlations were higher north of Point Reyes, where high settlement occurred only during relaxation, than south of Point Reyes, where settlement occurred both during relaxation events and to a lesser degree during upwelling. Overall crab settlement was higher south of Point Reyes. On a daily time scale, crab settlement north of Point Reyes was associated with the sharp increase in temperature observed as the relaxation current reached that point on the coast. This association suggested that crabs were transported northward alongshore in the thermal front which propagated northward during each relaxation event. This alongshore transport mechanism may be responsible for the predictable pattern of settlement variability within this system: with continuous, event-modulated settlement south of Point Reyes and episodic, event-dependent settlement to the north. Similar physical/biological interactions may occur at other points along this coast and along the midlatitude boundaries of other oceans.
\end{abstract}

KEY WORDS: Settlement - Upwelling · Space

\section{INTRODUCTION}

One of the obstacles to understanding the population dynamics of meroplanktonic, benthic marine invertebrates such as crabs and sea urchins is a lack of understanding of the causes of spatial variability in settlement and recruitment. While the recruitment dynamics of individual subpopulations of benthic invertebrates with dispersing larvae has been studied extensively (Underwood \& Denley 1984, Connell 1985, Gaines \& Roughgarden 1985, Roughgarden et al. 1985, 1988, Holm 1990), they are usually treated as separate, 'open' populations receiving a constant supply of

\footnotetext{
·E-mail:wing@megalopa.ucdavis.edu
}

propagules from an exogenous source. There is little understanding of the alongshore, spatial component of recruitment variability over the range of the complete, closed metapopulation formed by a number of subpopulations connected by larval dispersal. This variability is a consequence not only of differing habitat along the coast, but also of temporal and spatial variability in dispersal patterns within the metapopulation. Recent studies have shown that the latter may be as important to regional metapopulation dynamics as life history characteristics such as mortality rates and reproductive rates are to local subpopulation dynamics (e.g. Pulliam 1988, Possingham \& Roughgarden 1990, Botsford et al. 1994, Hastings \& Higgins 1994). In spite of this importance, the mechanisms controlling variability in along- 
shore dispersal between subpopulations have not been well studied (cf. Gaines \& Bertness 1993a, b).

Dispersal patterns of marine meroplanktonic larvae can be studied in a number of ways. Physical models of circulation in the coastal ocean can be used to infer movement of zooplankton with specific physical and behavioral characteristics (Hofmann et al. 1991, Botsford et al. 1994). Direct observation has been limited to species with relatively large larvae that disperse over relatively short distances (e.g. Olson 1985, Davis \& Butler 1989, Carlon \& Olson 1993). Another approach is to compare temporal variability in settlement at different locations on a variety of scales from meters to many kilometers (e.g. Caffey 1985, Judge et al. 1988, Rumrill 1988, Raimondi 1990, Sewell \& Watson 1993). A fourth approach, the one taken here, seeks to identify the physical mechanisms underlying larval dispersal by observing larval distributions and settlement over space and time concurrently with physical oceanographic conditions (e.g. Pedrotti \& Fenaux 1992).

In the California Current, mesoscale oceanographic features associated with wind forced currents and coastal topography may be important sources of settlement variability for some benthic invertebrates. The dynamics of wind driven coastal upwelling in the California Current have been linked to settlement and recruitment in several ways. For example, Ebert \& Russell (1988) argued, based on adult size distributions, that recruitment of purple sea urchins is strongly affected by the mesoscale variability in upwelling associated with headlands in northern California, USA. Graham et al. (1992) identified differences in zooplankton distribution between an 'upwelling shadow' in Monterey Bay, south of Point Año Nuevo, California, and adjacent waters. Investigators concerned specifically with recruitment of Dungeness crab have observed correlations between recruitment and upwelling (Peterson 1973, Botsford \& Wickham 1975), alongshore winds (Johnson et al. 1986) and alongshore geostrophic flow (McConnaughey et al. 1992). Recent studies monitoring barnacle recruitment have shown that larvae only return to settle in the intertidal zone during periods of upwelling relaxation, when the upwelling 'front' moves cross-shelf and 'collides' with the shore (Farrell et al. 1991, Roughgarden et al. 1991).

To explain the temporal variability in crab settlement north of Point Reyes off northern California during 1992, Wing et al. (1995) proposed that settlement was associated with alongshore as well as cross-shelf transport during upwelling relaxation. During the upwelling season on the northern California coast there are periods when cessation or slight reversal of upwelling winds results in an alongshore flow of

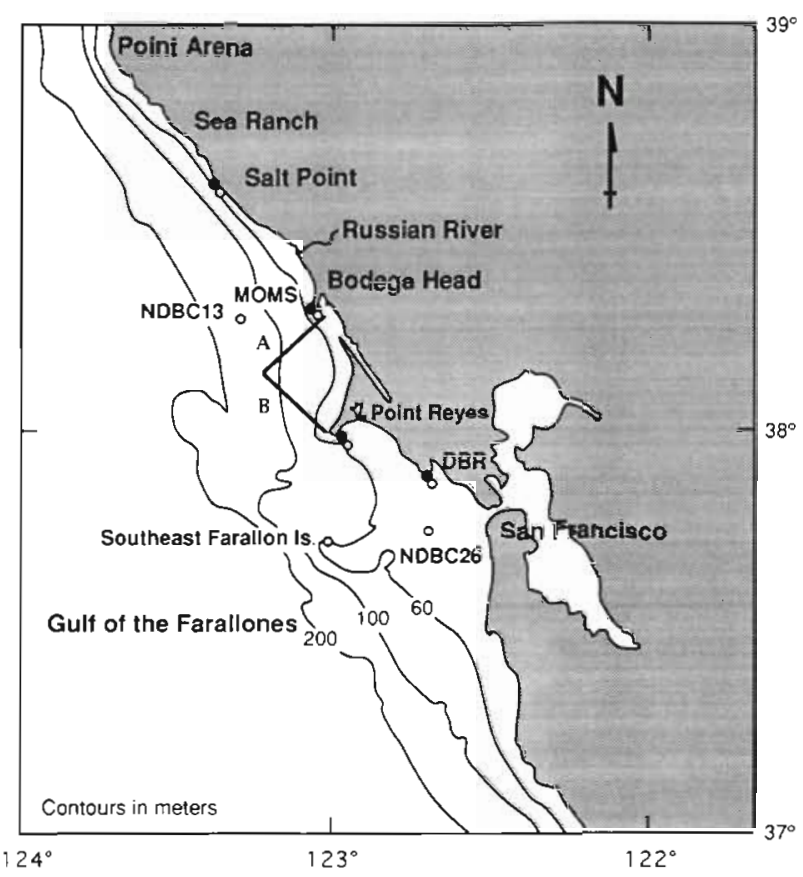

Fig. 1. Location of settlement sites $(\bullet)$ and oceanographic sampling sites, meteorological buoys (O), and 2 transects for CTD and plankton samples (A and B)

warm, low salinity water from the Gulf of the Farallones, poleward along the coast north of Point Reyes (Send et al. 1987, Largier et al. 1993, Wing et al. 1995) (Fig. 1). These relaxation currents are partially buoyancy forced and, by virtue of Coriolis effects, they remain coastally trapped as they flow poleward. They move alongshore over the inner shelf and midshelf from Point Reyes as far north as Point Arena. From the observation that crab settlement at Bodega Head, California, was associated with increasing temperature, Wing et al. (1995) proposed that planktonic crab larvae that had either accumulated in the Gulf of the Farallones or had moved onshore there were transported northward in such an alongshore coastal flow during upwelling relaxation. However, this study lacked information on the spatial variability of settlement across the region needed in order to compare the Gulf of the Farallones with points to the north.

The study described here is an attempt to improve our understanding of this potiential mechanism by monitoring settlement and temperature at 4 points along the coast and investigating the spatial pattern of the observed association between settiement and temperature. Here we measured spatio-temporal patterns of larval settlement"rates for several species of crabs (particularly Cancer spp.) and 2 species of sea urchins (Strongylocentrotus spp.) nearshore at Duxbury Reef $\left(37^{\circ} 53^{\prime} \mathrm{N}, 122^{\circ} 42^{\prime} \mathrm{W}\right)$ within the Gulf of the Farallones; Point Reyes ( $37^{\circ} 59^{\prime} \mathrm{N}, 122^{\circ} 58^{\prime} \mathrm{W}$ ) at the north- 
ern limit of the Gulf of the Farallones; Bodega Head $\left(38^{\circ} 18^{\prime} \mathrm{N}, 123^{\circ} 04^{\prime} \mathrm{W}\right.$ ) and Salt Point (38 $33^{\circ} \mathrm{N}, 123^{\circ}$ $19^{\prime} \mathrm{W}$ ) along the California coast north of Point Reyes but south of Point Arena (Fig. 1). We also measured cross-shelf distributions of planktonic crab larvae at Bodega Head during a relaxation feature. The resultant patterns of settlement were compared with time series of temperature collected at each site as well as temperature (including satellite images), salinity, wind velocity and sea level height from offshore and onshore sites. Results from this study elucidate a mechanism that may infiuence the spatial scale and magnitude of settlement variability across a large part of the northern California coast.

\section{LARVAL LIFE HISTORIES}

Because prevailing winds and currents vary seasonally along this coast, the way in which local circulation will influence settlement during the late larval period depends in part on the date of release and length of the larval period. During winter and early spring, nearshore flow near the surface is predominantly poleward and onshore. During spring (typically March-April), the winds shift from southerly to northerly, an event referred to as the spring transition (cf. Strub et al. 1987). Nearsurface water moves offshore and upwelling begins, leading to a strong equatorward jet over the shelf (cf. Largier et al. 1993, Wing et al. 1995). Larvae released nearshore earlier in the year, before upwelling begins, are likely to be found offshore of the coastal zone of upwelled water because they would have been transported offshore with these surface waters. Larvae released later, on the other hand, may be found within the cool upwelled water and are likely to be transported southward rapidly (cf. Richardson \& Pearcy 1977, Richardson et al. 1980).

Although the timing of larval release and development periods is not well known for all of the species of interest here, some generalities can be drawn. Cancer crabs are ovigerous early in the year and have relatively long larval periods, 80 to 160 d (Strathmann 1987). Dungeness crab Cancer magister larvae are released nearshore $(<50 \mathrm{~m})$ between December and March (Waldron 1958, Wild 1983), and may settle nearshore in May and June (Poole 1966, Carrasco et al. 1985, McConnaughey et al. 1992). C. productus is ovigerous between October and January and generally settles between February and September with peak settlement in May (Trask 1970. Strathmann 1987). Similarly, C. antennarius is found to be ovigerous between November and January and may be found settling at Bodega Bay in June through August (Morris et al. 1980, Wing et al. 1995). The porcellanid group (Pachycheles spp. and Petrolistes spp.) can be ovigerous in February through April; however, a second brood may be produced as late as August. This group has short larval periods, generally 34 to $40 \mathrm{~d}$ (cf. MacMillan 1972). Settlement of Pugettia spp. and Loxorhynchus spp. occurred in May-June at Bodega Head during the 1992 season; however, we lack information regarding the local reproductive timing and larval period (Wing et al. 1995). Spawning of red sea urchins Strongylocentrotus franciscanus may occur from March through July (Strathmann 1978, Kato \& Schroeter 1985), and purple sea urchins from December through June (Pearse et al. 1982, Strathmann 1987). Larval periods estimated from laboratory studies are 7 to $19 \mathrm{wk}$ for $S$. franciscanus and 4 to $12 \mathrm{wk}$ for $S$. purpuratus (Strathmann 1978, Cameron \& Schroeter 1980). In 1992, spawning of $S$. franciscanus occurred in April, and settlement of both species peaked in July in northern California (Wing et al. 1995).

To summarize, we studied several taxonomic groups within which species share similar characteristics. Cancer spp. crabs are released primarily before the spring transition and have a larval period that extends beyond the spring transition. Porcellanid crabs and purple sea urchins can be released both before and after upwelling starts, and have shorter larval periods. Red sea urchin larvae are released near the time of the spring transition or later, and they have a relatively short larval period.

\section{MATERIALS AND METHODS}

Oceanographic data. Oceanographic data used in this study were collected from a variety of sources. We obtained satellite AVHRR (advanced very high resolution radiometer) images of the region from the U.S. National Oceanic and Atmospheric Administration (NOAA), and time series of temperature from the Bodega Marine Laboratory (BML) at Bodega Head, NOAA buoys NDBC $46013\left(38^{\circ} 14^{\prime} \mathrm{N}, 123^{\circ} 20^{\prime} \mathrm{W}\right)$, $\mathrm{NDBC} 46026,\left(37^{\circ} 45^{\prime} \mathrm{N}, 122^{\circ} 42^{\prime} \mathrm{W}\right)$ and the Southeast Farallon Island field station $\left(37^{\circ} 42^{\prime} \mathrm{N}, 123^{\circ} 00^{\prime} \mathrm{W}\right)$ (Fig. 1). We also collected temperature time series at the $10 \mathrm{~m}$ isobath for each of our settlement collection sites at Duxbury Reef, Point Reyes, Bodega Head and Salt Point with small in situ temperature sensors sampling temperature at $24 \mathrm{~min}$ intervals. Salinity time series were collected at BML and Southeast Farallon Island; wind velocity and subsurface pressure were also collected at BML. BML data were collected as 20 min averages. Daily subsurface pressure data were obtained from a piezoelectric transducer mounted at $10 \mathrm{~m}$ depth off of Bodega Head. We filtered the $20 \mathrm{~min}$ data to remove tidal and diurnal signals using the WHOI PL64 filter (Limeburner 1985). 
Cross-correlations between daily alongshore $\left(317^{\circ}\right)$ wind stress at NB 46013 for April 1 through September 18, 1993 (Days 91 to 261) and daily temperature at each site were calculated for lags from 0 to $10 \mathrm{~d}$ following the methods of Kope \& Botsford (1988). $95 \%$ confidence intervals were calculated from the time series sample size $(n=160)$.

In addition, we collected information on temperature and salinity structure of the inner shelf during several upwelling and relaxation events. CTD (conductivity, temperature, depth) casts were made at $1.5 \mathrm{~km}$ intervals running out $15 \mathrm{~km}$ at $240^{\circ}$ from BML (line $A$ in Fig. 1), returning alongshore to the northern tip of Point Reyes (line B, Fig. 1). On these transects we also collected plankton from the surface layers (1 to $3 \mathrm{~m}$ ) using a $1 \mathrm{~m}^{2}$ Bongo net (115 $\mu \mathrm{m}$ mesh). Plankton samples were preserved in ethanol and sorted for presence of crab and sea urchin larvae.

Settlement. Settlement of crabs and sea urchins was determined roughly weekly from April 1 until September 4, 1993 (Days 91 to 247) at 4 sites along the coast: Duxbury Reef, Point Reyes, Bodega Head, and Salt Point (Fig. 1). At each site, we deployed 6 collectors over a $100 \mathrm{~m}$ length of the 10 to $12 \mathrm{~m}$ isobath. These arrays of collectors were exposed to the dominant ocean swell and on a rocky substratum. Retrieval of settlement collectors occurred on a 7 to $10 \mathrm{~d}$ interval and collectors at all sites were retrieved within a 24 to $48 \mathrm{~h}$ period when possible. During the period from July 18 until August 8, 1993 (Days 199 to 220), which overlapped an alongshore relaxation event, we sampled settlement at Bodega Head on a 2 to $4 \mathrm{~d}$ retrieval schedule separate from our regular weekly regime.

Each settlement collector consisted of four 7 inch (ca $18 \mathrm{~cm}$ ), wood-backed scrub brushes with polypropylene bristles, attached to a polypropylene line with net floats for buoyancy, anchored to the bottom with a $25 \mathrm{~kg}$ cement anchor so that when deployed they floated 0.5 to $1 \mathrm{~m}$ above the bottom. Upon retrieval, the collectors were washed in fresh water, and the resulting material was sorted for newly settled crabs and sea urchins which were fixed in ethanol for later identification.

Species identifications for crabs was accomplished using guidelines from Lough (1975) and Smith \& Carlton (1975). We identified 9 species of juvenile crabs: Cancer antennarius, C. productus, C. magister, Pachycheles spp., Petrolistes spp., Loxorhynchus spp., Pugettia spp., Pagarus spp., Hemigrapsus spp.; several species of megalopal stage larvae were also found. Sea urchins were identified using the methods of Rowley (1990) and R. Emlet (pers. comm.). We identified 2 species of sea urchins: Strongylocentrotus franciscanus and $S$. purpuratus. For this analysis we separated the crabs into 2 groups: Cancer spp., consisting of $C$. anntenarius, C. productus and C. magister; and total crabs, including all crab species.

Correlations between settlement of Cancerspp. and total crabs with site temperature were calculated by averaging site temperature over each settlement sampling period and calculating the correlation for the time series using a standard linear correlation statistic (Sokal \& Rohlf 1981). 95\% confidence levels were calculated based on sample size for each site $(n=15$ to 18). Correlations between settlement and salinity at Bodega Head were calculated by the same method. These correlations were calculated for the whole study period first; due to concern that the correlations were dominated by a single event in the early part of the season, we then calculated the correlations for the later part of the season separately (Days 163 to 247).

Intersite correlations for settlement of total crabs and Cancer spp. were calculated by obtaining averages of the settlement time series of all 4 sites over synchronous sampling periods ( $\mathrm{n}=13$ ). Sample periods that were collected within $24 \mathrm{~h}$ were considered synchronous in this analysis. These correlations were also scrutinized with a $95 \%$ confidence limit (i.e. $R>0.541$ ).

\section{RESULTS}

\section{Upwelling and relaxation features during 1993}

The 1993 upwelling season was marked by one major and several other relaxation events (Fig. 2). As in 1992 (Wing et al. 1995), temperature and salinity showed the expected response to periods of upwelling and relaxation in most instances. Periods of high equatorward alongshore wind stress (Fig. 2a) typically resulted in decreases in temperature (Fig. 2b) and sea level (Fig. 2d) and increases in salinity (Fig. 2c). Relaxation in equatorward wind stress resulted in lagged increases in temperature and sea level and decreases in salinity (Fig. 2). There were significant negative correlations between wind stress at NB 46013 and temperature for each of the study sites for lags from 0 to 10 d, typical of upwelling dynamics (cf. Brink 1983, Lentz 1987) (Fig. 3).

The extent to which temperature changes are due to surface heating can be estimated from calculation of the amount of solar warming to be expected based on the bulk equations of Gill (1982; meteorological data including solar irradiance are available from BML). This indicated that, as in 1981-1982 (Send et al. 1987) and 1992 (Wing et al. 1995), the water warmed faster than could be explained solely by solar heating (Fig. 2). Advection of warm water into the region is necessary to explain the rapid increase in water temperature. Similarly, advection is necessary to explain the con- 


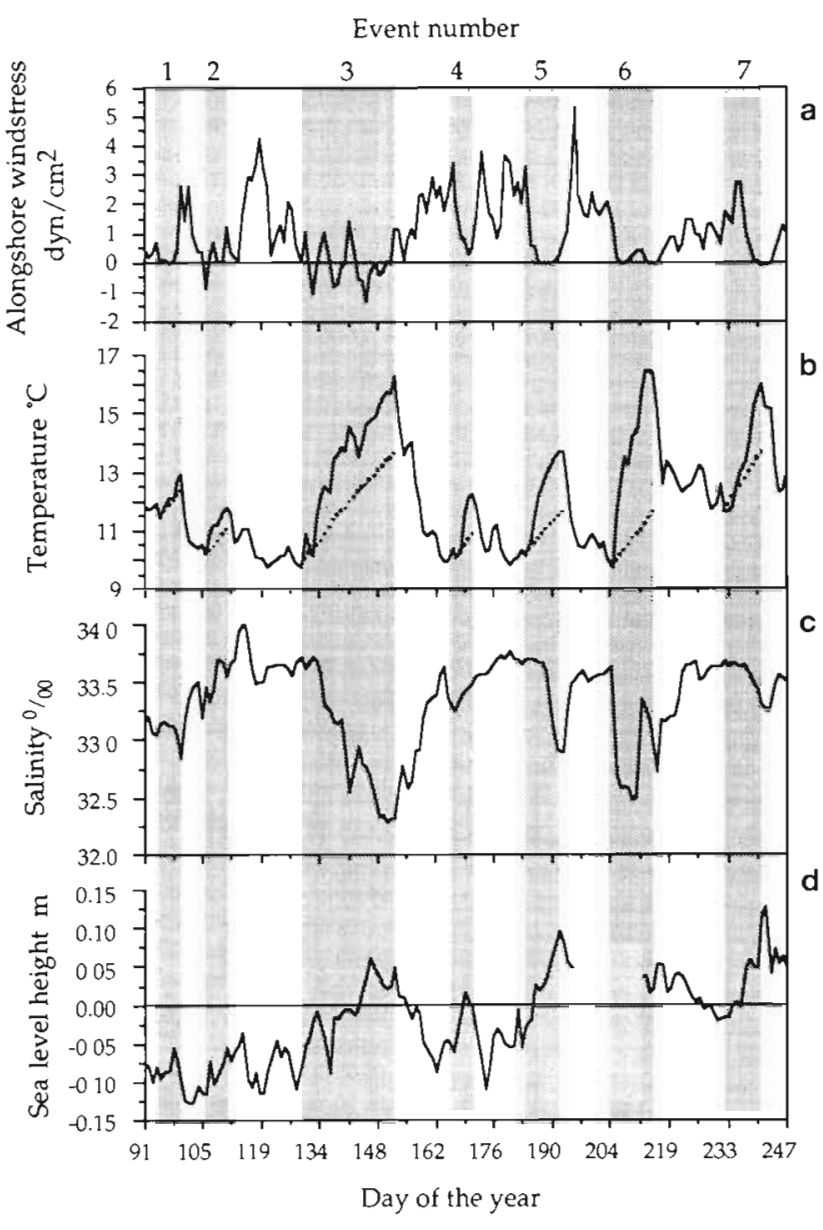

Fig. 2. Oceanographic and meteorological variables from Bodega Marne Laboratory and NB 46013. (a) dally average wind stress from $317^{\circ}$ at NB 46013 (i e. positive values are alongshore equatorward), (b) dally average temperature at $10 \mathrm{~m}$ (dotted lines are the calculated surface warming for each relaxation period), (c) dally average salinity and (d) deviatıons from dally average sea level height. Shaded areas: relaxation events on the basis of temperature increases greater than those predicted by solar warming of the surface (cf Send et al 1987) Blank area in sea level height record is a group of missing data

comitant decrease in salinity during the longer relaxatıons in upwelling wind

It is this correlated temperature-salinity signal, in response to relaxation in local upwelling winds, that we used as an indication of an advective inflow of nonupwelled water. Warm poleward flows over the shelf were observed directly in current-meter data from relaxation events during the Coastal Ocean Dynamics Experiment (CODE) and the Northern California Coastal Circulation Study (NCCCS) which showed that during relaxations there is a poleward flowing warm water current along the inner shelf that may extend from the Gulf of the Farallones as far north as Point Arena. These features can be seen clearly in ear-

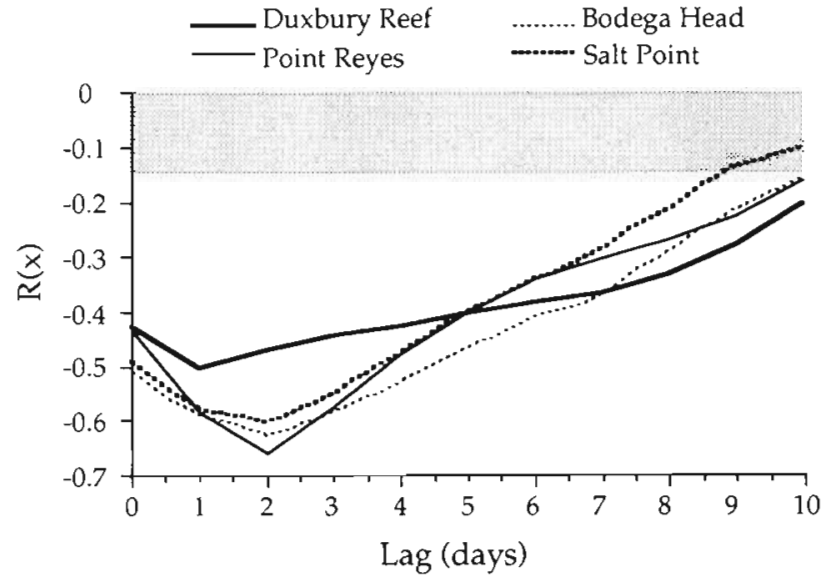

Fig. 3. Correlations between alongshore wind stress (at NB 46013) and temperature at each of the 4 settlement sites calculated for April 1 through September 18, 1993 (Days 91 to 261). Sample size for the time senes with lags calculated from 0 to $10 \mathrm{~d}$ is $160, \mathrm{p}<005$ at $\mathrm{R}>0154$. Shaded region $95 \%$ confidence limit. Note the lag in cooling at all sites typical of coastal upwelling

lier AVHRR images of the region [e.g. Send et al. (1987, Plate 1), Largier et al. (1993, Fig. 7b) and Wing et al. (1995, Fig. 6)]. Similar warming events during 1993 are marked as shaded bars in Fig. 2. These are penods when the rate of warming is greater than that due to calculated surface heating, and temperature nses by more than $1^{\circ} \mathrm{C}$. Calculated surface heating is marked as a dashed line for each of these warming periods. Note that Events 1, 2 and 4 were very weak warming periods and probably do not reflect significant alongshore flow. In contrast, Events 3, 5, 6 and 7 were longer lasting, exhibiting large increases in temperature and concomitant decreases in salinity.

Patterns of near-coastal circulation during upwelling and relaxation are well represented by AVHRR images from 1993. A typical pattern of surface temperature during upwelling shows a center of cooler water next to the coast just south of Point Arena, extending in a jet equatorward and offshore near Point Reyes (Fig. 4a). Note the anticyclonic flow immediately to the south of Point Reyes in Drakes Bay, suggesting entrainment of newly upwelled and offshore water into the region. Also note larger-scale eddy features centered offshore of Point Arena and in the Gulf of the Farallones. An image from later in the season llustrates a relaxation event involving a coastally trapped warm feature propagating poleward on the inner shelf (Fig. 4b). Between Days 212 (July 31) and 214 (August 2) during relaxation Event 6 this feature moved from just north of Bodega Head to just south of Point Arena (Image not shown) in the $49 \mathrm{~h}$ between the 2 images. AVHRR


son show similar patterns. 

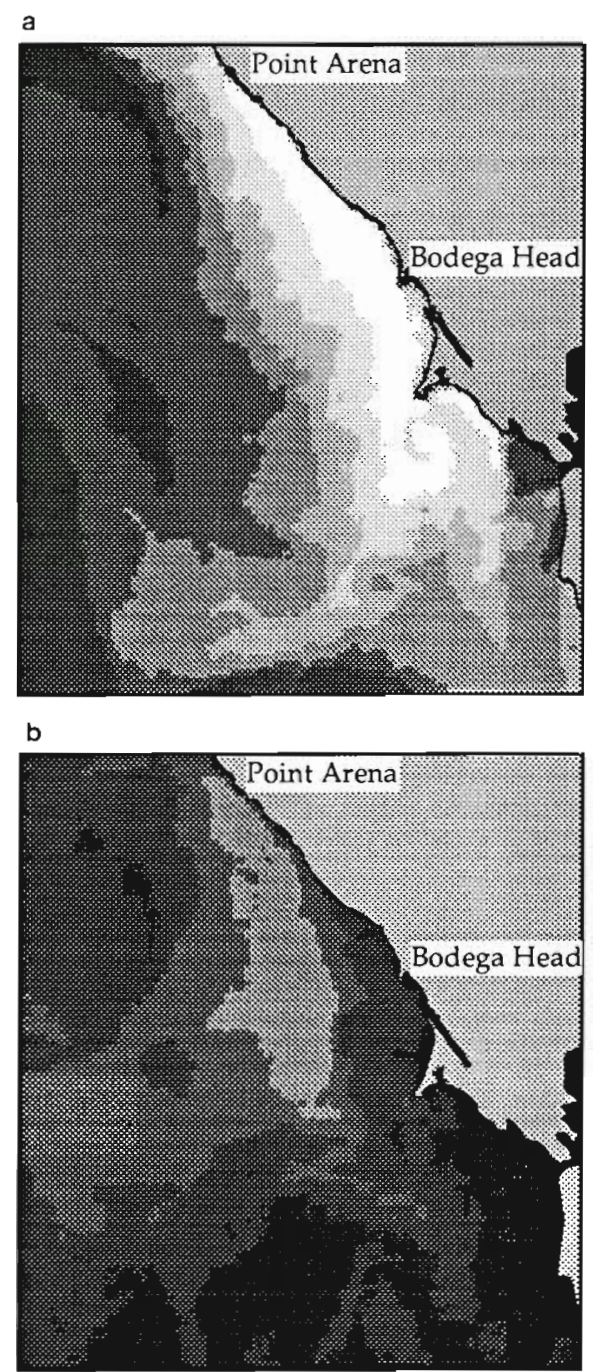

Fig. 4. AVHRR images of surface temperature on Days (a) 163 (June 12, 23:00 h GMT), (b) 212 (July 31, 15:00 h GMT). The temperature scale ranges from approximately $9^{\circ} \mathrm{C}$ light grey to approximately $16^{\circ} \mathrm{C}$ for the darkest grey

The spatio-temporal patterns of flow during upwelling and relaxation are reflected in the temperatures recorded at the array of coastal thermistors. Warm water events vary in duration and alongshore extent, being more frequent and lasting longer at the Gulf of the Farallones sites, while more episodic and ephemeral on the coast north of Point Reyes (Fig 5). Temperature increases occur sequentially from south to north, especially during the later part of the season, whereas temperature decreases occur more synchronously alongshore (cf. Fig. 6).

Surface temperature differences between the offshore sites (i.e. the 2 offshore buoys and Southeast Farallon Island), and the onshore sites (i.e. Bodega Head, Point Reyes and Duxbury Reef) indicate the cross-shelf thermal differences during upwelling and relaxation

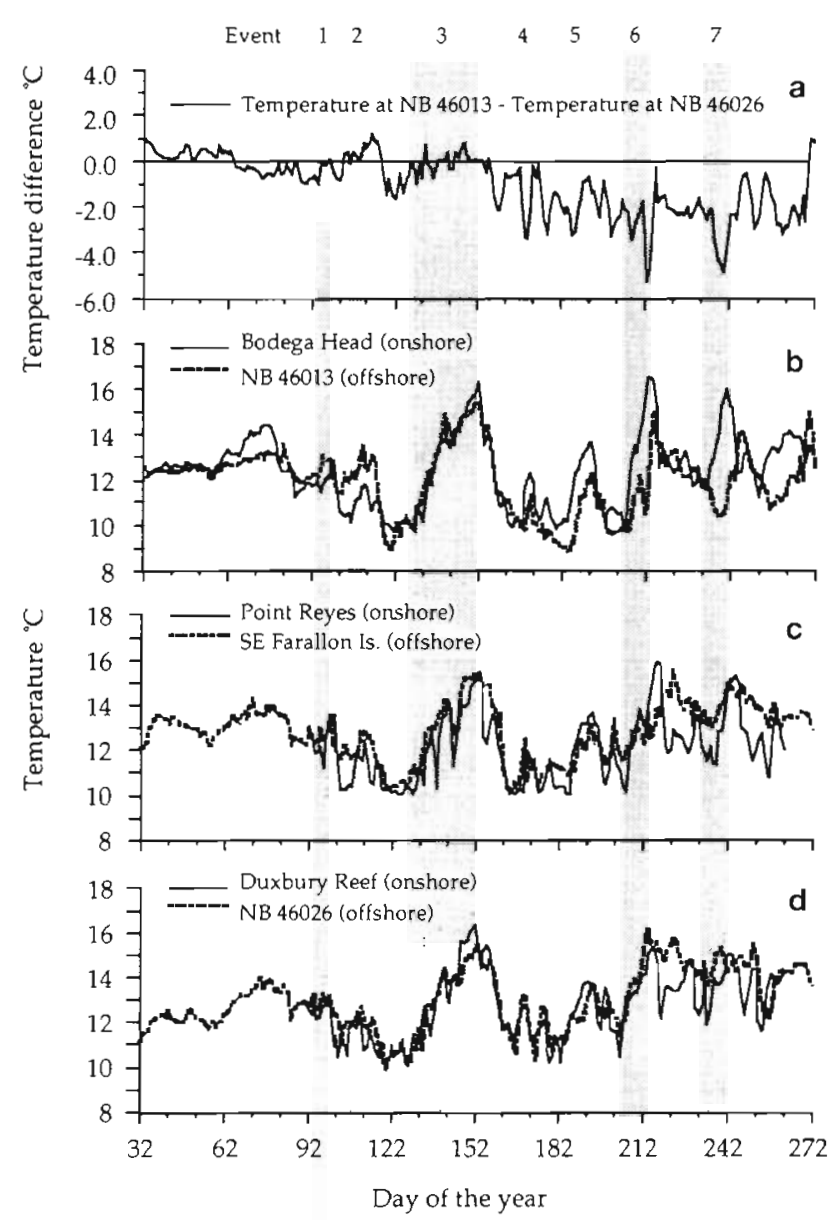

Fig. 5. Spatial differences in average daily temperature: (a) north-south difference in temperature indicated by differences between NOAA buoys NB 46013 and NB 46026 ; (b to d) temperatures at cross-shelf pairs of stations. Solid lines: onshore sites; dashed lines: offshore sites (as indicated in Fig. 1)

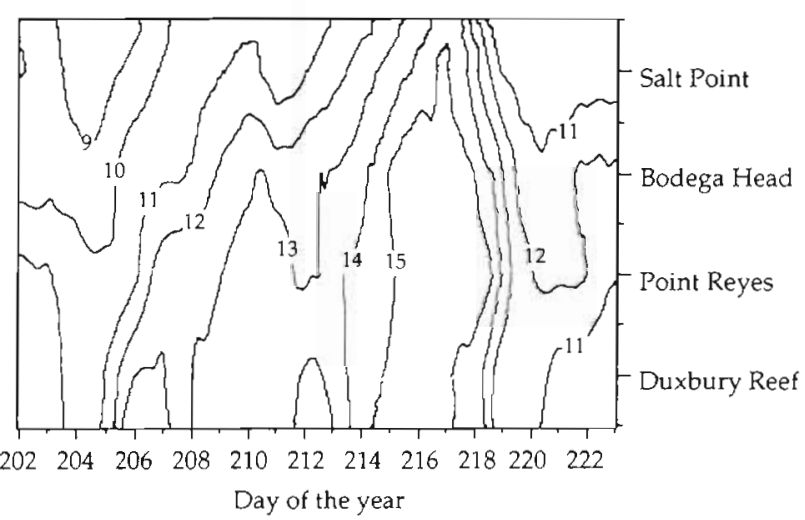

Fig. 6. Spatial variability of temperature during Event 6 shows progression of warming from south to north across the 4 settlement sites as the alongshore current propagates poleward during Days 205 to 216 (July 24 to August 4). Note the rapid and more uniform cooling at all sites markung the beginning of upwelling on Day 218 (August 6). Temperature is collected as daily averages at $10 \mathrm{~m}$ at each settlement site 
(Fig. 5). During the later part of the season (1.e. after Day 152, June 1), it was generally warmer in the Gulf of the Farallones than north of Point Reyes (Fig. 5a), providing a reservoir of warm low-density water which could propagate northward as a buoyancy current. During relaxation events in this late summer period, warming at NB 46013 occurred later than warming at Bodega Head (Fig. 5b), indicating that the front of this thermal feature was at an angle to the coast (roughly NE-SW), consistent with the wedge shape evident in satellite images (cf. Fig. 4b). Cooling, on the other hand, occurrs relatively synchronously at the onshore and offshore sites. This same lag in warming was not seen between the 2 southern comparison sites in the Gulf of the Farallones (Fig. 5c, d), indicating that warming and cooling occurred closer to the same time nearshore than offshore (i.e. onshore advection or broad alongshore advection). During the early part of the season (i.e. before Day 152), there was no persistent temperature difference between north and south (Fig. 5a), and relaxation events involved uniform shelfwide warming, suggesting onshore relaxation flows. An exception was warming Event 2.

The physical conditions associated with relaxation Event 2 are of special interest because of an unusually large settlement of purple sea urchins and porcellanid crabs, primarily at Point Reyes. During the upwelling period prior to relaxation Event 2, coastal temperatures dropped $3^{\circ} \mathrm{C}$ to about $10^{\circ} \mathrm{C}$ while offshore temperatures decreased only slightly, resulting in a cross-shelf temperature difference over the shelf at Bodega Head (Fig. 5b) and at Point Reyes (Fig. 5c), but no substantial difference at the most southern parr of stations (Fig. 5d). When the wind subsided on Day 104, the warmer water returned to shore at Point Reyes, but not at Bodega Head where the cross-shelf temperature difference persisted.

\section{Settlement results}

Weekly settlement data show a large early season peak (Days 91 to 119) for crabs other than Cancer spp. (mainly due to porcellanid crabs) at Point Reyes, but low settlement at the other sites (Figs. $7 \& 8$ ). This early season event accounted for $45 \%$ of the total crab settlement at Point Reyes during the study period. Also during this period there was a large settlement of sea urchins that accounted for $100 \%$ of seasonal settlement at Point Reyes. As described above, coastal temperature had increased and the cross-shelf temperature difference had disappeared at Point Reyes, which may indicate the arrival of non-upwelled water durnng this event (Fig. 5). At the other coastal sites, temperatures did not decrease, indicating that the non-

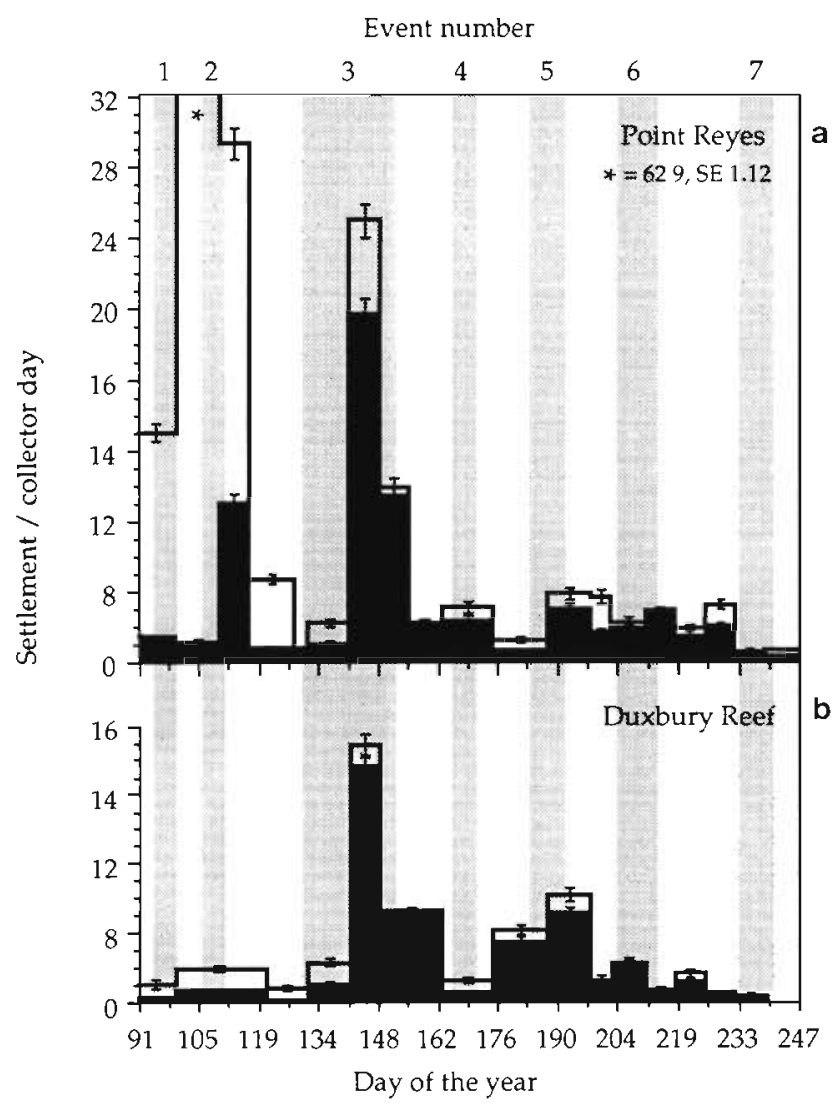

Fig. 7 Settlement per collector day of total crabs (solid line) and Cancer spp (dark bars) at the 2 Gulf of the Farallones sites (d) Point Reyes, (b) Duxbury Reef Each value in the tume series shows the beginning and end of a sample period as width of the bars SEs are based on an assumed Poisson distribution Shaded regions: warming events as calculated in Fig 2

upwelling water did not intersect the coast at the other sites.

Following this event there was a large settlement of Cancer spp. at all 4 sites during Event 3, a region-wide relaxation from upwelling conditions that lasted $24 \mathrm{~d}$. In terms of total crab abundance, this event was a large fraction of total settlement for the season, particularly at the 2 northern sites: Salt Point $(30 \%)$ and Bodega Head (38\%) versus $10 \%$ at Point Reyes and $25 \%$ at Duxbury Reef. For Cancer spp. settlement, this event accounted for $56 \%$ at Salt Point, $20 \%$ at Bodega Head, $28 \%$ at Point Reyes, and $28 \%$ at Duxbury Reef. Following this large settlement event in late May, there was a series of smaller settlement events at the 2 northern sites that were associated with shorter relaxation events (Fig. 8). However, at the southern sites, settlement of crabs did not appear to be dependent on warming events, and settlement stayed relatively high even during upwelling conditions (Fig. 7).

Intersite correlations indicated different alongshore settlement patterns for different taxa. Cancer spp. set- 


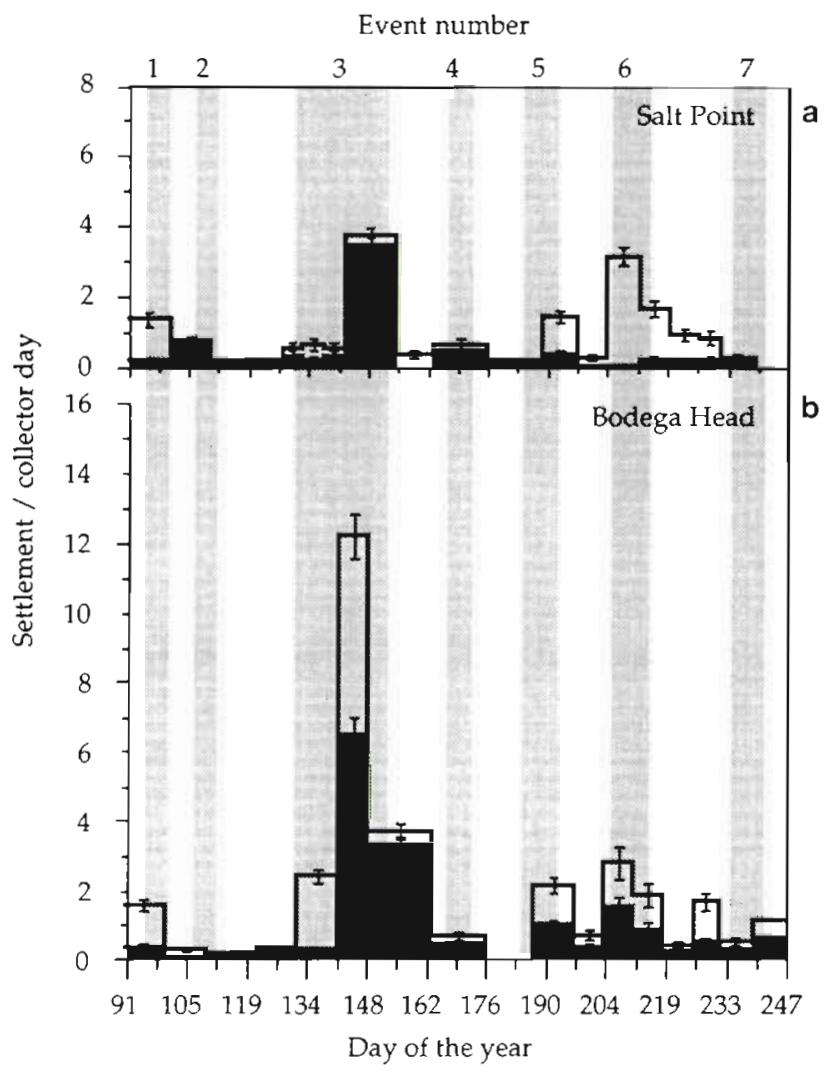

Fig. 8. Settlement per collector day of total crabs (solid line) and Cancer spp. (dark bars) at the 2 northern sites; (a) Salt Point, (b) Bodega Head. Each value in the time series shows the beginning and end of a sample period as width of the bars. SEs are based on an assumed Poisson distribution.

Shaded regions: warming events as calculated in Fig. 2

tlement was highly correlated between sites (Table 1), reflecting an apparent synchrony of Cancer crab settlement across the 4 sites. It should be noted that this correlation is largely due to the high settlement during Event 3. While intersite correlations for total crabs were significant between the 2 northern sites and Duxbury Reef, correlations for total crab settlement between Point Reyes and the other 3 sites were not significant. This result is primarily due to the large early season settlement of crabs other than the Cancer species, which occurred only at Point Reyes (Table 1).

Correlations of total crab and Cancer spp. settlement during each sample period with average temperature for that sample period at that site indicated a stronger association of settlement with warm events at the northern sites (Bodega Head and Salt Point) than at the 2 southern sites (Table 2). A similar pattern
Table 1. Correlations among total crab and among Cancer spp. settlement at different sites. Numbers in bold indicate significant correlations [i.e. $p>0.05$ at $R(x)>0.541, n=13$ ]

\begin{tabular}{|lcccc|}
\hline & $\begin{array}{c}\text { Salt } \\
\text { Point }\end{array}$ & $\begin{array}{c}\text { Bodega } \\
\text { Head }\end{array}$ & $\begin{array}{c}\text { Point } \\
\text { Reyes }\end{array}$ & $\begin{array}{c}\text { Duxbury } \\
\text { Reef }\end{array}$ \\
\hline Total crabs & & & & \\
Salt Point & 1 & $\mathbf{0 . 6 9 3}$ & -0.027 & 0.329 \\
Bodega Head & & 1 & 0.0729 & $\mathbf{0 . 6 8 2}$ \\
Point Reyes & & & 1 & 0.0931 \\
Duxbury Reef & & & & 1 \\
Cancerspp. & & & & \\
Salt Point & 1 & $\mathbf{0 . 9 0 8}$ & $\mathbf{0 . 9 6 8}$ & $\mathbf{0 . 7 3 3}$ \\
Bodega Head & & 1 & $\mathbf{0 . 9 3 8}$ & $\mathbf{0 . 8 0 4}$ \\
Point Reyes & & & 1 & $\mathbf{0 . 7 7 7}$ \\
Duxbury Reef & & & & 1 \\
\hline
\end{tabular}

existed for the negative correlation between settlement at each site and average salinity during each sample period at Bodega Head (Table 2). At the Point Reyes site, correlations of total crab settlement with site temperature and with salinity at Bodega Head are near zero because settlement was dominated by the influence of the unique, early season porcellanid settlement event (Table 2). In fact, most of these correlations at Point Reyes are significant, despite a reduced sample size, if the early season event is removed (total crabs vs site temperature, $\mathrm{R}=0.473_{\text {; }}$ Cancer $\mathrm{spp}$. vs site temperature, $\mathrm{R}=0.528$; total crabs vs salinity at Bodega Head, $\mathrm{R}=-0.650$; Cancer spp. vs salinity at Bodega Head, $R=-0.714)(n=14$; i.e. $p<0.05$ at $R=$ $0.521)$.

These patterns indicate that settlement north of Point Reyes occurs during conditions associated with relaxation (i.e. lower salinity and increased temperature), whereas in the Gulf of the Farallones, settlement occurs more persistently, even during upwelling conditions. Although it may appear that this result is dependent on Event 3, correlations between salinity at Bodega Head and total settlement at Bodega Head ( $\mathrm{R}=$ -0.868 ) and Salt Point ( $R=-0.769)$ remain significant

Table 2. Correlations of total crab and Cancer spp. settlement with average site temperature and salinity at. Bodega Head for each sample period. Numbers in bold indicate significant correlations, $\mathrm{p}<0.05$

\begin{tabular}{|c|c|c|c|c|c|}
\hline & \multicolumn{2}{|c|}{$\begin{array}{l}\text { Site temperature } \\
\text { versus: }\end{array}$} & \multicolumn{2}{|c|}{$\begin{array}{c}\text { Salınity at Bodega Head } \\
\text { versus: }\end{array}$} & \multirow[t]{2}{*}{$\begin{array}{l}\text { Sample } \\
\text { size }\end{array}$} \\
\hline & $\begin{array}{l}\text { Total } \\
\text { crab }\end{array}$ & $\begin{array}{l}\text { Cancer } \\
\text { spp. }\end{array}$ & $\begin{array}{l}\text { Total } \\
\text { crab }\end{array}$ & $\begin{array}{l}\text { Cancer } \\
\text { spp. }\end{array}$ & \\
\hline Salt Point & 0.655 & 0.667 & -0.788 & -0.616 & 17 \\
\hline Bodega Head & 0.650 & 0.622 & -0.742 & -0.763 & 16 \\
\hline Point Reyes & -0.062 & 0.447 & -0.081 & -0.549 & 18 \\
\hline Duxbury Reef & 0.349 & 0.417 & -0.588 & -0.621 & 15 \\
\hline
\end{tabular}



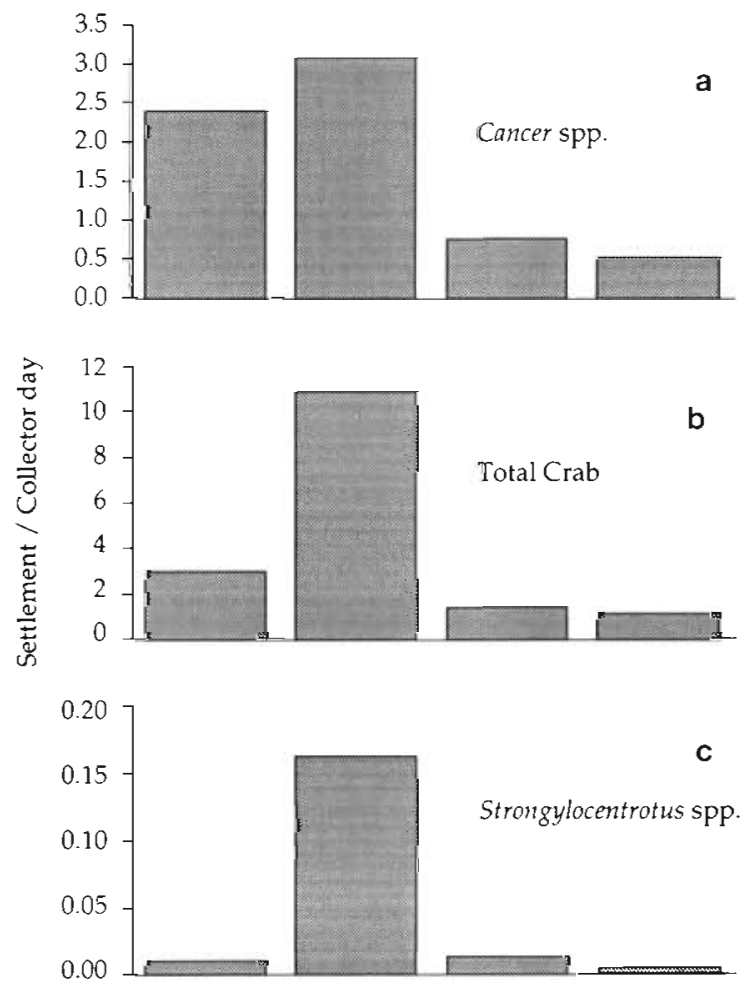

Duxbury Reef Point Reyes Bodega Head Salt Point

Fig. 9. Distribution of total seasonal settlement rate (per collector day) at each settlement site for the 3 taxonomic groups. Sample sizes for collection periods were: Salt Point 17. Bodega Head 16, Point Reyes 18 and Duxbury Reef 15. Collections were made from April 1 (Day 91) through September 4, 1993 (Day 247)

when the influence of Event 3 is removed by calculating correlations for Days 163 to $247(\mathrm{n}=10, \mathrm{p}<0.05$ at $\mathrm{R}=0.616$ ). These correlations are also significant for Cancer spp. and salinity at Bodega Head $(R=-0.836)$ using the truncated data series.

Total seasonal settlement across the 4 sites exhibited a consistent north-south difference and the unusually large settlement of crabs at Point Reyes (Fig. 9). For Cancer spp., total settlement at the 2 Gulf of the Farallones sites averaged 5 times greater than settlement north of Point Reyes (Fig. 9a). Total crab and total sea urchin settlement both showed highest settlement at Point Reyes due to the early season settlement event (Fig. 9b, c).

\section{High resolution temporal and spatial sampling of settlement}

The results from weekly sampling in 1992 (Wing et al. 1995) and 1993 suggest an association between settlement and relaxation events. However, to understand the physical-biological mechanism underlying this relationship we need finer-scale temporal sampling to determine the timing of settlement within relaxation events. In 1993, we were able to sample more frequently during Event 6.

The northward propagation of warm water in Event 6 is indicated by the lag in warming across the 4 sites (Fig. 6). This is the event depicted in the AVHRR image (Fig. 4b) as a warm, wedge-shaped current trapped over the shelf, similar to the poleward flow events described by Send et al. (1987) and Largier et al. (1993). Direct CTD observations of the cross-shelf thermal structure during relaxation Event 6 (on Day 210) confirmed the thermal structure reflected in the AVHRR image (Fig. 4b). Concurrent plankton samples indicate an association between warmer non-upwelled water and planktonic crab larvae. The 2 sets of CTD casts (transects A and B in Fig. 1) indicated a lens of warm water which is generally thicker along the coast and appears to be separated immediately north of Point Reyes (Figs. 10b \& $11 \mathrm{~b}$ ). A clear thermocline was seen at 10 to $20 \mathrm{~m}$. The concurrent larval densities indicate that crab larvae tend to be associated with the warmer water (Figs. 10a \& 11a). No urchin larvae were found in these tows. Five days later the feature had moved poleward. A similar survey revealed a deeper
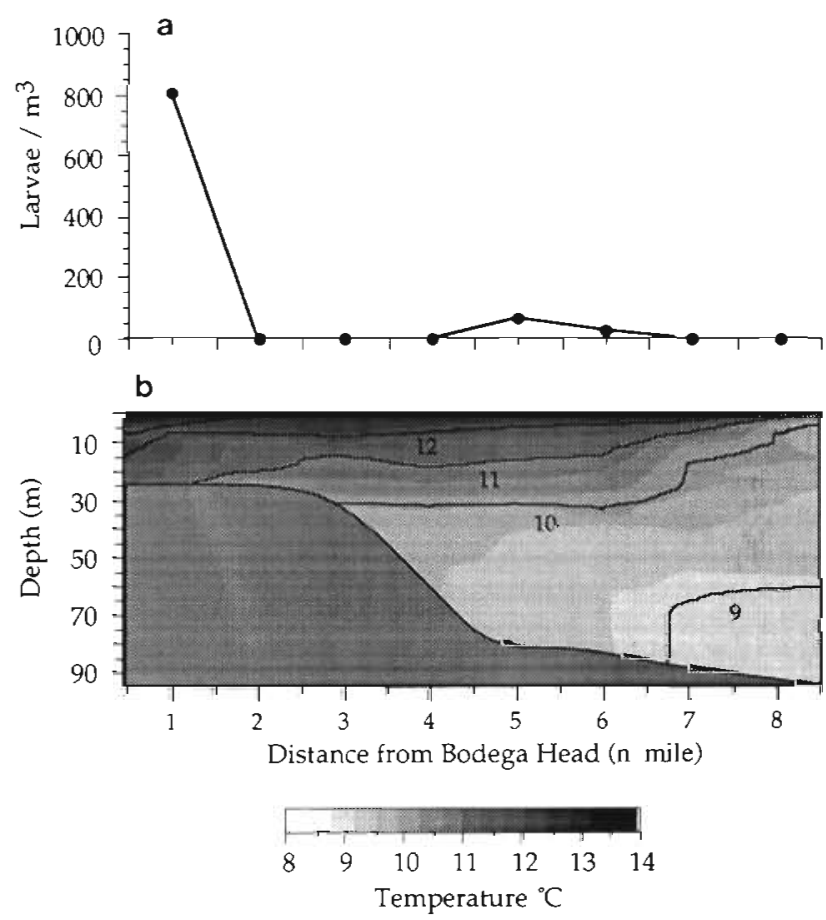

Fig. 10. Total planktonic crab larval density and temperature vs depth along transect A (Fig. 1) on Day 210 (July 29) during passage of warm surface current during relaxation Event 6. Distance along the transect from Bodega Head is given on the abscissa in nautical miles 

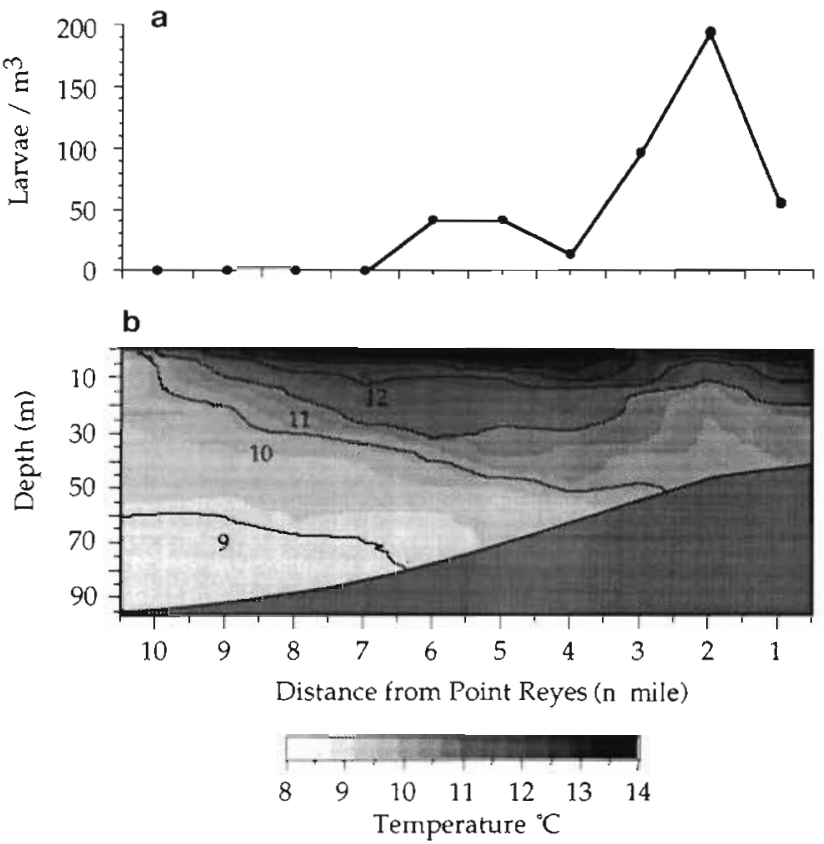

Fig. 11 Total planktonic crab larval density and temperature vs depth along transect B (Fig. 1) on Day 210 (July 29) during passage of warm surface current during relaxation Event 6 . Distance along the transect from Point Reyes is given on the abscissa in nautical miles

and sharper thermocline (data not shown), and larval densities were lower.

Comparison of tine-scale settlement with local temperature at Bodega Head during relaxation Event 6 indicates that most crabs settled over a period that overlapped the beginning of the event. Fig. 12 shows the beginning of relaxation Event 6 as a period of rapid warming when a thermal front passed Bodega Head



Fig. 12. Total crab settlement sampled at 2 to 4 d intervals during passage of relaxation Event 6 . Temperature was collected at $10 \mathrm{~m}$ depth off of Bodega Head and is plotted in $24 \mathrm{~min}$ intervals. Note that the highest settlement period (Days 203 to 207. July 22 to July 26) overlapped the onset of rapid warming on Day 205 (July 24) signaling the beginning of relaxation Event 6 on Day 205. It should be noted that peak settlement can also occur during the middle of a long warming period (i.e. Event 3).

\section{DISCUSSION}

The important link between upwelling variability and benthic settlement, described for barnacles in Monterey Bay (Farrell et al. 1991, Roughgarden et al. 1991) and for crabs off Bodega Bay (Wing et al. 1995), is central to the understanding of local recruitment. In this work we have expanded this local view to show that settlement is not homogeneous alongshore, but rather may be tied to alongshore structure in hydrodynamic features. In particular, we have described a possible mechanism by which larvae of one taxon, Cancer crabs, settle to the north of a coastal promontory (Point Reyes) after being transported there by a flow of warm, low salinity water from south of this promontory during periods of upwelling relaxation. South of Point Reyes some settlement of this taxon occurs during upwelling, and the settlement rate increases during relaxation periods. Identification of a link between physical conditions and settlement over this part of the life history is an important addition to our understanding of the dynamics of recruitment to these and similar populations in the embayment from Point Arena to Point Reyes, and may have implications for other similar embayments to the north in the California Current, and in other eastern boundary currents.

Data presented here and elsewhere provide support for both the physical and biological components of this proposed mechanism. Past observations of temperature-current patterns (Send et al. 1987), drifter tracks (Davis 1985a, b) and movement of an oil spill from the Gulf of the Farallones (Breaker \& Bratkovitch 1993) provided evidence that the Gulf of the Farallones is the source of the warm water that reaches the ReyesArena coast during relaxation, specifically during the later upwelling season. Our conclusion that this water contains high densities of meroplanktonic larvae that are transported poleward from the Gulf during relaxation, and constitute the main supply of propagules, is based on several lines of evidence. First, Cancer crab settlement north of Point Reyes is more tightly correlated with low salinity and high temperatures than is settlement within the Gulf of the Farallones. These are the conditions that indicate alongshore relaxation currents. Correlations between settlement and salinity at the 2 northern sites are still significant even when the largest event of the season (Event 3) is removed by truncating the data, indicating that the spatial result is relatively robust. In addition, total seasonal settlement north of Point Reyes is less than to the south. Fine tem. 
poral sampling of settlement at Bodega Head shows settlement of crabs at the beginning of a relaxation feature that propagates poleward along the coast (Figs. 6 $\&$ 12). Cross-shelf larval crab distributions during this same relaxation event (Figs. 10 \& 11) showed close association of planktonic larvae with the warm poleward moving current, particularly the shoreward edge of this feature.

Despite these lines of evidence, several qualifications must accompany our conclusions. First, we have not shown that larvae are transported in the alongshore flow, only that settlement patterns observed here, in Wing et al. (1995), and in the limited data on larval distribution are consistent with this scenario. Another possible explanation is that larvae are resident at each site and settle in response to warm, low salinity conditions. More data are needed on the alongshore distributions of planktonic larvae to more concretely describe larval supply during relaxation events. Second, it is not clear to what extent the water in the Gulf of the Farallones is entrained from southward shelf flow, supplied by shoreward flow of offshore water into the Gulf, or composed of San Francisco Bay water. Third, there is a need for observation of more events over several years before we can draw conclusions regarding the frequency of the observed pattern on annual time scales. Finally, it must be noted that correlations between variables that indicate physical transport phenomena and settlement rates are often problematical because larval availability may vary between similar transport events.

Whether other species of invertebrates and fish in this or similar embayments are influenced by the alongshore transport mechanism proposed here depends on the specific, underlying, physical-biological interactions. As we have shown, alongshore settlement variability is species specific, possibly depending on timing of larval release, larval life period, duration of the competency phase and a host of other factors in larval development. Our results suggest that the species whose settlement patterns are most consistent with our proposed mechanism are those with the largest, longest lived, and most actively swimming larvae, that probably also have a relatively long competency period (Cancer spp.). In contrast, those species with shorter larval duration, smaller larvae and probably shorter competency periods appear more likely to be associated with single events or a small number of relaxation events early in the season (the porcellanid group). For example, sea urchins, with relatively short larval periods and small weakly swimming larvae, fall into this second pattern. We surmise that species with these characteristics may have less reliable settlement in this system and less spatial integrity of settlement.
These results add an alongshore component to interpretation of earlier studies that focused primarily on the effects of cross-shelf transport on successful recruitment. Explanations of reproductive strategies (Parrish et al. 1981) and cross-shelf larval zonation (Peterson 1973, Richardson \& Pearcy 1977, Richardson et al. 1980) depended on the cross-shelf effects of upwelling. Observation of the link between barnacle settlement and temporal, variability in this cross-shelf effect led to the 'tattered curtain hypothesis' (Farrell et al. 1991, Roughgarden et al. 1991): during periods of upwelling relaxation, the upwelling front moves closer to shore resulting in settlement of barnacles that were concentrated in the upwelling front several $\mathrm{km}$ offshore. The mechanism proposed in this paper shifts the focus from one of recruitment success in response to cross-shelf processes to one of recruitment distribution in response to 3 -dimensional coastal circulation. It indicates that the same source of temporal variability (i.e. upwelling/relaxation) is responsible for alongshore redistribution of propagules.

This alongshore aspect expands the suite of potential physical-biological influences on recruitment of meroplanktonic species along the northern California coast. Most importantly, it describes the larval interactions between spatially distributed subpopulations, not just local temporal variability in recruitment. For example, our results indicate that there may be retention mechanisms so that larvae released near the coast after the spring transition are not simply swept south. Rather, recirculating regions such as those found in northern Monterey Bay (Graham et al. 1992) and in the northern Gulf of the Farallones (suggested in this paper, in Largier et al. 1993, and in Wing et al. 1995) may provide regions with predictably high settlement relative to neighboring upwelling areas. Our results also indicate that the larvae that settle in this Point Reyes-Point Arena embayment may be derived from a common planktonic pool that collects in the Gulf of the Farallones. The spatio-temporal variability in larval dispersal implied by these characteristics has important implications for metapopulation dynamics and management of these coastal populations (cf. Pulliam 1988, Botsford et al. 1994).

Acknowledgements. We gratefully acknowledge the Gulf of the Farallones National Marine Sanctuary for the use of their vessel, and Bodega Marine Laboratory, Ocean Cove Campground, Salt Point State Park, Point Reyes National Seashore, Sea Drift community, and Point Reyes Bird Observatory (California, USA); and Kym Arico, David Wilson, Carolyn Lundquist, Jim Leichter, Jim Quinn, H. V. S. Peeke, and Robert Morgan for other forms of assistance. This article was funded by a grant from the National Sea Grant College Program, National Oceanic and Atmospheric Administration, U.S. Department of Commerce, Washington, DC, under grant number NA89AA-D-5G138, project numbers R/F-136 and 
R/F-150 through the California Sea Grant College, and in part by the California State Resources agency. The authors' views expressed herein do not necessarily reflect those of NOAA or any of its sub-agencies. The U.S. Government is authorized to reproduce and distribute this article for governmental purposes.

\section{LITERATURE CITED}

Botsford LW, Moloney CL, Hastings A, Largier JL, Powell TM, Higgins K, Quinn JF (1994) The influence of spatially and temporally varying oceanographic conditions on meroplanktonic metapopulations. Deep Sea Res II 41:107-145

Botsford LW, Wickham DE (1975) Correlation of upwelling index and Dungeness crab catch. Fish Bull US 73:901-907

Breaker LC, Bratkovich A (1993) Coastal-ocean processes and their influence on the oil spilled off San Francisco by the M/V Puerto Rican. Mar environ Res 36:153-184

Brink KH (1983) The near-surface dynamics of coastal upwelling. Prog Oceanogr 12:223-257

Caffey HM (1985) Spatial and temporal variation in settlement and recruitment of intertidal barnacles. Ecol Monogr 55:313-332

Cameron RA, Schroeter SC (1980) Sea urchin recruitment effect of substrate selection of juvenile distribution. Mar Ecol Prog Ser 2:243-247

Carlon DB, Olson RR (1993) Larval dispersal distance as an explanation for adult spatial pattern in two Caribbean reef corals. J exp mar Biol Ecol 173:247-263

Carrasco KR, Armstrong DA, Gunderson DR, Rogers C (1985) Abundance and growth of Cancer magister young-of-theyear in the nearshore environment. In: Melteff BR (ed) Proceedings of the symposium on Dungeness crab biology and management. Alaska Sea Grant Prog Rep 85-3, University of Alaska, Anchorage

Connell JH (1985) The consequences of variation in initial settlement vs post-settlement mortality in rocky intertidal communities. J exp mar Biol Ecol 93:11-45

Davis AR, Butler AJ (1989) Direct observations of larval dispersal in the colonial ascidian Podoclavella moluccensis Sluiter: evidence for closed populations. J exp mar Biol Ecol 127:189-203

Davis RE (1985a) Drifter observations of coastal surface currents during CODE: the method and descriptive view. J geophys Res 90:4741-4755

Davis RE (1985b) Drifter observations of coastal surface currents during CODE: the statistical and dynamical views. $J$ geophys Res 90:4756-4772

Ebert TA, Russell MP (1988) Latitudinal variation in size structure of the west coast purple sea urchin: a correlation with headlands. Limnol Oceanogr 33:286-294

Farrell TM, Bracher D, Roughgarden J (1991) Cross-shelt transport causes recruitment to intertidal populations in central California. Limnol Oceanogr 36:279--288

Gaines S, Roughgarden J (1985) Larval settlement rate: a leading determinant of structure in an ecological community of the marine intertidal zone. Proc Natl Acad Sci USA 82:3707-3711

Gaines SD, Bertness MD (1993a) The dynamics of juvenile dispersal - why field ecologists must integrate. Ecology $74: 2430-2435$

Gaines SD, Bertness MD (1993b) Dispersal of juveniles and variable recruitment in sessile marine species. Nature 360 : $579-580$

Gill AE (1982) Atmosphere-ocean dynamics. Academic Press, New York
Graham WM, Field JG, Potts DC (1992) Persistent 'upwelling shadows' and their influence on zooplankton distributions. Mar Biol 114:561-570

Hastings A, Higgins K (1994) Persistence of transients in spatially structured ecological models. Science 263:1133-1136

Hofmann EE, Hedstrom KS, Moisan JR, Haidvogel DB, Mackas DL (1991) Use of simulated drifter tracks to investigate general transport patterns and residence times in the coastal transition zone. J geophys Res 96:15041-15052

Holm ER (1990) Effects of density-dependent mortality on the relationship between recruitment and larval settlement. Mar Ecol Prog Ser 60:141-146

Johnson DF, Botsford LW, Methot RD Jr, Wainwright TC (1986) Wind stress and cycles in Dungeness crab (Cancer magister) catch off California, Oregon and Washington. Can J Fish Aquat Sci 43:838-845

Judge L, Quinn JF, Wolin CL (1988) Variability in recruitment of Balanus glandula (Darwin, 1854) along the central California coast. J exp mar Biol Ecol 119:235-251

Kato S, Schroeter SC (1985) Biology of the red sea urchin, Strongylocentrotus franciscanus, and its fishery in California. Mar Fish Rev 47:1-20

Kope RG, Botsford LW (1988) Detection of environmental influence on recruitment using abundance data. Can J Fish Aquat Sci 45:1448-1458

Largier JL, Magnell BA, Winant CD (1993) Subtidal circulation over the northern California shelf. J geophys Res 98 : $18147-18179$

Lentz SJ (1987) A heat budget for the northern California shelf during CODE 2. J geophys Res 92:1545-1568

Limeburner R (1985) CODE-2: moored array and large scale data report. WHOI Tech Rep 85-35, WHOI, Woods Hole

Lough RG (1975) Larval dynamics of the Dungeness crab, Cancer magister, off the central Oregon coast, 1970-71. Fish Bull US 74:353-375

MacMillan FE (1972) The larval development of northern California Porcellanidae (Decapoda, Anomura). I. Pachycheles pubescens Holmes in comparison to Pachycheles rudis Stimpson. Biol Bull 142:57-70

McConnaughey RA, Armstrong DA, Hickey BM, Gunderson DR (1992) Juvenile Dungeness crab (Cancer magister) recruitment variability and oceanic transport during the pelagic larval phase. Can J Fish Aquat Sci 49:2028-2044

Morris RH, Abbott DP, Haderlie EC (1980) Intertidal invertebrates of California. Stanford University Press, Stanford

Olson RR (1985) The consequences of short-distance larval dispersal in a sessile marine invertebrate. Ecology 66 $30-39$

Parrish RH, Nelson CS, Bakun A (1981) Transport mechanisms and reproductive success of fishes in the California current. Biol Oceanogr 1:175-203

Pearse JS, Pearse VB, Davis KK (1982) Photoperiodic regulation of gematogenesis and growth in the sea urchin Strongylocentrotus purpuratus. J exp Zool 237:107-118

Pedrotti ML, Fenaux L (1992) Dispersal of echinoderm larvae in a geographical area marked by upwelling (Ligurian Sea, N.W. Mediterranean). Mar Ecol Prog Ser 86:217-227

Peterson WT (1973) Upwelling indices and annual catches of Dungeness crab, Cancer magister, along the west coast of the United States. Fish Bull US 71:902-910

Poole RL (1966) A description of laboratory reared zoeae of Cancer magister Dana, and megalopae taken under natural conditions (Decapoda, Brachyura). Crustaceana 11: $83-97$

Possingham HP, Roughgarden J (1990) Spatial population dynamics of a marine organism with a complex life cycle. Ecology 71:973-985 
Pulliam HR (1988) Sources, sinks and population regulation. Am Nat 132:652-661

Raimondi PT (1990) Patterns, mechanisms, consequences of variability in settlement and recruitment of an intertidal barnacle. Ecol Monogr 60:283-309

Richardson SL, Laroche JL, Richardson MD (1980) Larval fish assemblages and associations in the north-east Pacific Ocean along the Oregon coast, winter-spring 1972-1975. Estuar coast mar Sci 11:671-699

Richardson SL, Pearcy WG (1977) Coastal and oceanic fish larvae in an area of upwelling off Yaquina Bay, Oregon. Fish Bull US 75:125-145

Roughgarden J, Gaines S, Possingham H (1988) Recruitment dynamics in complex life cycles. Science 241:1460-1466

Roughgarden J, Iwasa Y, Baxter C (1985) Demographic theory for an open marine population with space-limited recruitment. Ecology 66:54-67

Roughgarden J, Pennington JT, Stoner D, Alexander S, Miller $\mathrm{K}$ (1991) Collisions of upwelling fronts with the intertidal zone: the cause of recruitment pulses in barnacle populations of central California. Acta Oecologia 12:35-51

Rowley RJ (1990) Newly settled sea urchins in a kelp bed and urchin barren ground: a comparison of growth and mortality. Mar Ecol Prog Ser 62:229-240

Rumrill SS (1988) Temporal and spatial variability in the intensity of recruitment of a sea star: frequent recruitment and demise. Am Zool 28:123

Send U, Beardsley RC, Winant CD (1987) Relaxation from upwelling in the Coastal Ocean Dynamics Experiment. J geophys Res 92:1683-1698

Sewell MA, Watson JC (1993) A 'source' for asteroid larvae?: recruitment of Pisaster ocraceus, Pycnopodia helianthoides and Dermasterias imbricata in Nootka Sound, British Columbia. Mar Biol 117:387-398

This article was submitted to the editor
Smith RI, Carlton JT (1975) Light's manual: intertidal invertebrates of the Central California coast. University of California Press, Berkeley, p 393-412

Sokal RR, Rohlf FJ (1981) Biometry, 2nd edn. WH Freeman and Co, San Francisco

Strathmann MF (1987) Reproduction and development of marine invertebrates of the northern Pacific coast. University of Washington Press, Seattle

Strathmann RR (1978) Length of pelagic period in echinoderms with feeding larvae from the northeast Pacific. $J$ exp mar Biol Ecol 34:23-27

Strub PT, Allen JS, Huyer A, Smith RL, Beardsley RC (1987) Seasonal cycles of currents, temperatures, winds, and sea level over the northeast Pacific continental shelf. J geophys Res 92:1507-1526

Trask T (1970) A description of laboratory-reared larvae of Cancer productus Randall (Decapoda, Brachyura) and a comparison to larvae of Cancer magister Dana. Crustaceana 18:133-146

Underwood AJ, Denley EJ (1984) Paradigms, explanations, and generalizations in models for the structure of intertidal communities on rocky shores. In: Strong DR, Simberloff $\mathrm{D}$, Abele LG, Thistle AB (eds) Ecological communities: conceptual issues and evidence. Princeton University Press, Princeton, p 151-180

Waldron KD (1958) The fishery and biology of the Dungeness crab (Cancer magister Dana) in Oregon waters. Fish Comm Ore Contrib 24:1-43

Wild P (1983) Effects of seawater temperature on spawning, egg development, and hatching success of the Dungeness crab (Cancer magister). Fish Bull US 172:197-213

Wing SR, Largier JL, Botsford LW, Quinn JF (1995) Settlement and transport of benthic invertebrates in an intermittent upwelling region. Limnol Oceanogr 40:316-329

Manuscript first received: October 6, 1994

Revised version accepted: May 23, 1995 